\title{
Antitumor Activity of Biflorin, an o-Naphthoquinone Isolated from Capraria biflora
}

\author{
Marne Carvalho de Vasconcellos, ${ }^{a}$ Daniel Pereira Bezerra, ${ }^{a}$ Aluísio Marques Fonseca, ${ }^{b}$ \\ Márcio Roberto Pinho Pereira, ${ }^{a, d}$ Telma Leda Gomes Lemos, ${ }^{b}$ Otília Deusdênia Loiola PessoA, ${ }^{b}$ \\ Cláudia Pessoa, ${ }^{a}$ Manoel Odorico de Moraes, ${ }^{a}$ Ana Paula Negreiros Nunes Alves, ${ }^{c}$ and \\ Letícia Veras Costa-Lotufo ${ }^{*, a}$ \\ ${ }^{a}$ Departamento de Fisiologia e Farmacologia, Faculdade de Medicina, Universidade Federal do Ceará; Caixa Postal- \\ 3157, 60430-270, Fortaleza, Ceará, Brasil: ${ }^{b}$ Departamento de Química Orgânica e Inorgânica, Universidade Federal do \\ Ceará; Caixa Postal-12200, 60021-940 Fortaleza, Ceará, Brasil: ${ }^{c}$ Departamento de Clínica Odontológica da Faculdade \\ de Farmácia, Odontologia e Enfermagem, Universidade Federal do Ceará; Fortaleza, Ceará, Brasil: and ${ }^{d}$ Centro de \\ Ciências da Saúde, Universidade de Fortaleza; Ceará, Brasil. $\quad$ Received October 16, 2006; accepted April 28, 2007
}

\begin{abstract}
Pharmacological studies with an aqueous extract obtained from leaves of Capraria biflora showed potent cytotoxic, analgesic, antimicrobial and anti-inflammatory activities. It has been demonstrated that biflorin possesses an in vitro cytotoxic activity against tumor cells. The in vivo antitumor activity of biflorin was evaluated on two mouse models, sarcoma 180 and Ehrlich carcinoma. Biflorin was active against both tumors with a very similar profile. In addition, biflorin was also able to increase the response elicited by 5-FU in mice inoculated with both tumors. The results showed a decrease in Ki67 staining in tumor cells from treated-animals when compared with non-treated groups, which suggests an inhibition of tumor proliferation rate. Histopathological analysis from kidneys and liver showed that biflorin possessed weak and reversible toxic effects. It was also demonstrated that biflorin acts as an immunoadjuvant agent, rising the production of ovalbumin-specific antibodies and inducing a discreet increase of the white pulp and nest of megakaryocytic in spleen of treated mice, which can be related to its antitumor properties.
\end{abstract}

Key words Capraria biflora; biflorin; sarcoma 180; Ehrlich carcinoma; antitumor activity

Capraria biflora L. (Scrophulariaceae) is a perennial shrub distributed in North and South America. Its leaves are used to treat pain, fever, flu, vomiting, childbirth recovery, diarrhea, hemorrhoids, rheumatism, and swelling, ${ }^{1,2)}$ while the roots have antibacterial properties. ${ }^{3)}$ Potent cytotoxic, analgesic and anti-inflammatory activities were demonstrated in pharmacological studies with an aqueous extract of $C$. biflora leaves. ${ }^{4-6)}$

From the aerial parts of C. biflora, two iridoids, harpagide and caprarioside, and the insecticidal sesquiterpenoids, caprariolides A, B, C and D, have been isolated, ${ }^{7,8)}$ while biflorin (6,9-dimethyl-3-(4-methyl-3-pentenyl)naphtha[1,8-bc]pyran-7,8-dione), an antimicrobial $o$-naphthoquinone, was isolated from the roots of $C$. biflora. ${ }^{9,10)}$ This compound is strongly active against gram-positive and alcohol-acid-resistant germs. ${ }^{11)}$ In another study, it was demonstrated that biflorin is also strongly active towards cultured tumor cells, inhibiting the proliferation on five tumor cell lines in a dose dependent manner as analyzed through MTT assay. ${ }^{12)}$ Nonetheless, biflorin did not inhibit the development of sea urchin embryos, neither did it induce lysis on mouse erythrocytes. Opposite of what is most commonly observed with other cytotoxic naphthoquinones, biflorin does not induce oxidative stress. $^{12)}$

In this study, the in vivo antitumor activity of biflorin was demonstrated using sarcoma 180 and Ehrlich carcinoma transplanted in mice. The effectiveness of the association of biflorin and 5-flourouracil (5-FU) was also assessed. The histopathological and morphological examination of the tumor and the animal organs, including liver, spleen and kidney, were performed to determine toxicological aspects of biflorin treatment. It was also demonstrated that biflorin acts as an immunoadjuvant agent, increasing ovalbumin (OVA) immunostimulant properties, which can be related to its antitumor properties.

\section{MATERIALS AND METHODS}

Reagents 5-Fluorouracil, $O$-phenylenidiamine dihydrochloride, ovalbumine were purchased from Sigma Chemical Co., St. Louis, MO, U.S.A.; avidin-biotin-peroxidase complex and diaminobenzidine were from Dako, Carpinteria, CA, U.S.A. Monoclonal mouse anti-human Ki-67 antigen was purchased from DAKO, Glostrup, Denmark. Goat antimouse IgG, A, M was from Serotec, Kidlington, Oxford, U.K. All other reagents were of analytical grade.

Isolation of Biflorin Capraria biflora was collected at a plantation located in Fortaleza, Ceará, Brazil, in April 2005 and identified by Dr. Edson Nunes. A voucher specimen (No. 30848) was deposited in the Herbarium Prisco Bezerra of the Departamento de Biologia of Universidade Federal do Ceará.

Air-dried powdered roots $(6 \mathrm{~kg})$ were extracted with light petroleum (41) for $2 \mathrm{~d}$. The extract was partially evaporated at room temperature until the formation of a solid material. The later was filtered under vacuum and yielded a purple solid $(2 \mathrm{~g})$. The purple solid material was chromatographed on Si gel and isocratic elution using a binary mixture of light petroleum/EtOAc 9:1 (v/v). Fractions were pooled together according to thin-layer chromatographic (TLC) analysis. Combined fractions having the purified biflorin yielded $1.5 \mathrm{~g}$. Structure determination of biflorin (Fig. 1) was determined by spectroscopy analysis, including one and two dimensional NMR spectral data, IR, physical properties and comparison with data from literature. ${ }^{10)}$ 


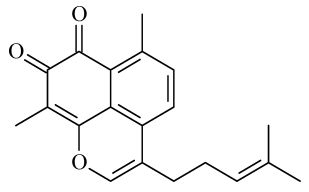

Fig. 1. Chemical Structure of Biflorin (6,9-Dimethyl-3-(4-methyl-3-pentenyl)naphtha[1,8-bc]-pyran-7,8-dione)

Assay of Antitumor Activity A total number of 140 Swiss mice (female, $20-30 \mathrm{~g}$ ) obtained from the central animal house of the Universidade Federal do Ceará, Brazil, were used. Animals were housed in cages with free access to food and water. All animals were kept under a $12 \mathrm{~h}: 12 \mathrm{~h}$ lightdark cycle (lights on at 6:00 a.m.). Sarcoma 180 and Ehrlich carcinoma tumor cells were maintained in the peritoneal cavities of the mice.

Ten-day-old sarcoma 180 or Ehrlich carcinoma ascites tumor cells were removed from the peritoneal cavity of bearing-mice, counted and implanted subcutaneously into right hind groin of experimental mice $\left(2 \times 10^{6}\right.$ cell $\left./ 500 \mu \mathrm{l}\right)$. One day after inoculation, biflorin alone $(25,50 \mathrm{mg} / \mathrm{kg}), 5-\mathrm{FU}$ alone $(10$ or $25 \mathrm{mg} / \mathrm{kg})$ or biflorin $(25 \mathrm{mg} / \mathrm{kg})$ plus $5-\mathrm{FU}$ $(10 \mathrm{mg} / \mathrm{kg})$ were dissolved in DMSO $10 \%$ and administered intraperitoneally for $7 \mathrm{~d}$. The negative control was injected with DMSO $10 \%$. On day 8 , the mice were sacrificed. Tumors, livers, spleens and kidney were extirpated, weighed and fixed in formaldehyde $10 \%$. Inhibition ratio (\%) was calculated by following formula: inhibition ratio $(\%)=$ $[(\mathrm{A}-\mathrm{B}) / \mathrm{A}] \times 100$, where $\mathrm{A}$ is average tumor weight of the negative control, and $\mathrm{B}$ is that of the treated group.

Histopathology and Morphological Observations After the dissection, tumors, livers, spleens and kidneys were fixed in formaldehyde $10 \%$, and examined grossly for size, color and hemorrhage. A portion of the tumor, liver, spleen and kidneys were cut into small pieces and, later, the histological sections $(5 \mu \mathrm{m})$ were prepared and stained with hematoxylin and eosin. Histological analyses were performed under light microscopy.

Ki67 Immunohistochemical Detection The following method was described previously by our group. ${ }^{13,14)}$ Tumor sections were deparaffinized with xylene and dehydrated with ethanol. The slides were then immersed in water for $10 \mathrm{~min}$. For antigen retrieval, the slides were boiled in citrate buffer ( $\mathrm{pH} \mathrm{6.0)}$ for $15 \mathrm{~min}$ in a microwave and subsequently cooled for $20 \mathrm{~min}$. The slides were then washed in TBS, and the endogenous peroxidases were blocked by $0.3 \%$ hydrogen peroxide for $15 \mathrm{~min}$. After washing with TBS, the sections were incubated overnight at $4{ }^{\circ} \mathrm{C}$ with mouse antibodies for $\mathrm{Ki}-67$ at the concentration of $1: 50$. After $24 \mathrm{~h}$, the slides were washed and incubated with a multilink antibody for $20 \mathrm{~min}$, washed in TBS and incubated for $20 \mathrm{~min}$ with avidin-biotin-peroxidase complex. After washing with TBS, the slides were incubated for $3 \mathrm{~min}$ with diaminobenzidine, and finally, counter-stained with hematoxylin prior to mounting. The percentage of proliferating neoplastic cells was evaluated directly under optical microscope. To quantify the amount of proliferation, all Ki67-positive cells were counted in 6 random fields per slide.

Subcutaneous Immunization Two groups of 10 swiss mice (provided by the Central Animal House of Universidade Federal do Ceará) had been immunized subcutaneously with OVA (50 $\mu \mathrm{g}$, group 1) or with OVA $(50 \mu \mathrm{g})+$ biflorin ( $1 \mathrm{mg} /$ animal or $40 \mathrm{mg} / \mathrm{kg}$, group 2). The mice were bled from the retro-orbital plexus to obtain sera prior to immunization and at 7,14 and $21 \mathrm{~d}$ after.

Measurement of OVA-Specific Antibody OVA-specific total Ig antibodies in serum were detected by enzyme-linked immunosorbent assay (ELISA). Purified OVA (50 $\mu$ g protein) diluted in saline solution, at a final volume of $100 \mu$, were used to coat the 96-well plates. The plates were incubated at $37^{\circ} \mathrm{C}$ for $1 \mathrm{~h}$ and washed three times with $0.05 \%$ PBS-tween. The plates were blocked with $5 \%$ nonfat milk in $10 \mathrm{~mm}$ potassium phosphate buffer, $\mathrm{pH} 7.2$, with $0.9 \% \mathrm{NaCl}$ (PBS) for $2 \mathrm{~h}$ at $37^{\circ} \mathrm{C}$, washed once, and $100 \mu \mathrm{l}$ of the appropriate sera diluted in PBS $(1: 10$ to $1: 1280)$ was added and reincubated for $2 \mathrm{~h}$ at $37^{\circ} \mathrm{C}$. The plates were washed again three times with $0.05 \%$ PBS-tween and treated with peroxidaseconjugated rabbit antimouse total immunoglobulins (100 $\mu \mathrm{l} /$ well, $1: 1000$ final dilution) for $2 \mathrm{~h}$ at room temperature. The plates were subsequently washed three times with PBS-tween. The reaction was developed by the addition of orthophenylenediamine followed by incubation for $20 \mathrm{~min}$ at $37^{\circ} \mathrm{C}$. The intensity of the resulting color was read at $450 \mathrm{~nm}$.

Statistical Analysis Data are presented as mean \pm S.E.M. from $n$ experiments. The differences between experimental groups were compared by ANOVA followed by Student Newman Keuls $(p<0.05)$.

\section{RESULTS}

Effects of biflorin on mice transplanted with sarcoma 180 and Ehrlich carcinoma tumors are presented in Tables 1 and 2. It was observed a significant reduction of tumor weight in biflorin treated animals at both doses and both tumor models $(p<0.05)$.

Histopathological analysis of the tumors extirpated from sarcoma 180 and Ehrlich carcinoma control mice showed groups of large, round and polygonal cells, with pleomorphic shapes, hyperchromatic nuclei and binucleation (Fig. 2). Several degrees of cellular and nuclear pleomorphism were seen. Mitosis, muscle invasion and coagulation necrosis were also noticed. In the tumors extirpated from animals treated with biflorin at $50 \mathrm{mg} / \mathrm{kg} / \mathrm{d}, 5-\mathrm{FU}$ at $25 \mathrm{mg} / \mathrm{kg} / \mathrm{d}$ or the association of biflorin $(25 \mathrm{mg} / \mathrm{kg} / \mathrm{d})$ plus $5-\mathrm{FU}(10 \mathrm{mg} / \mathrm{kg} / \mathrm{d})$, extensive areas of coagulative necrosis were observed, while in the groups treated with biflorin $(25 \mathrm{mg} / \mathrm{kg} / \mathrm{d})$ or $(5-\mathrm{FU} 10$ $\mathrm{mg} / \mathrm{kg} / \mathrm{d}$ ) there was only a discreet increase of the areas with coagulative necrosis.

Ki67 staining for cell proliferation was performed on sarcoma 180 tumors removed on day 8 from the untreated animals and treated with $5-\mathrm{FU}(10 \mathrm{mg} / \mathrm{kg} / \mathrm{d})$, biflorin $(25$, $50 \mathrm{mg} / \mathrm{kg} / \mathrm{d})$ or the association of biflorin $(25 \mathrm{mg} / \mathrm{kg} / \mathrm{d})$ with 5 -FU $(10 \mathrm{mg} / \mathrm{kg} / \mathrm{d})$. Nuclear staining and good preservation of morphological details were observed in all tumors sections immunostained with Ki67 antibody. Figure 3 shows the amount of Ki67 positive cells in analyzed slides. Results from this analysis show that the relative number of Ki67-positive tumor cells was substantially smaller in tumors from mice treated with 5-FU and biflorin at both doses and with the association (biflorin $+5-\mathrm{FU}$ ) than in control tumors $(p<0.05)$. 
Table 1. Inhibition Rate of Compounded Drugs on Mice Transplanted Sarcoma 180 Tumor

\begin{tabular}{|c|c|c|c|c|c|c|c|}
\hline Drug & $\begin{array}{c}\text { Dose } \\
(\mathrm{mg} / \mathrm{kg} / \mathrm{d})\end{array}$ & $\begin{array}{c}\text { Liver } \\
\text { (g/100 g body } \\
\text { weight) }\end{array}$ & $\begin{array}{c}\text { Spleen } \\
\text { (g/100 g body } \\
\text { weight) }\end{array}$ & $\begin{array}{l}\text { Kidney } \\
\text { (g/100 g body } \\
\text { weight) }\end{array}$ & Tumor (g) & Inhibition (\%) & $n$ \\
\hline Control & - & $5.21 \pm 0.16$ & $0.65 \pm 0.02$ & $1.16 \pm 0.04$ & $1.78 \pm 0.09$ & - & 20 \\
\hline \multirow[t]{2}{*}{ Biflorin } & 25 & $5.47 \pm 0.19$ & $0.78 \pm 0.03^{a)}$ & $1.25 \pm 0.05$ & $1.51 \pm 0.07$ & 14.89 & 14 \\
\hline & 50 & $5.17 \pm 0.10$ & $0.71 \pm 0.05$ & $1.00 \pm 0.04$ & $0.88 \pm 0.14^{a)}$ & 50.53 & 10 \\
\hline \multirow[t]{2}{*}{$5-\mathrm{FU}$} & 10 & $5.73 \pm 0.30$ & $0.50 \pm 0.03^{a)}$ & $1.25 \pm 0.06$ & $1.07 \pm 0.10^{a)}$ & 39.84 & 10 \\
\hline & 25 & $5.12 \pm 0.31$ & $0.30 \pm 0.03^{a, b, c)}$ & $1.68 \pm 0.08$ & $0.46 \pm 0.08^{a)}$ & 74.19 & 13 \\
\hline Biflorin $+5-F U$ & $25+10$ & $4.57 \pm 0.28^{b)}$ & $0.54 \pm 0.04^{a, b)}$ & $1.11 \pm 0.13$ & $0.61 \pm 0.11^{a, c)}$ & 65.83 & 10 \\
\hline
\end{tabular}

Data are presented as mean \pm S.E.M. from $n$ experiments. Significant differences were evaluated by ANOVA followed Student Newman Keuls: $a$ ) $p<0.05$ compared to control group. b) $p<0.05$ compared to biflorin $25 \mathrm{mg} / \mathrm{kg} / \mathrm{d}$. c) $p<0.05$ compared to biflorin $25 \mathrm{mg} / \mathrm{kg} / \mathrm{d}$ and $5-\mathrm{FU} 10 \mathrm{mg} / \mathrm{kg} / \mathrm{d}$ independently administered.
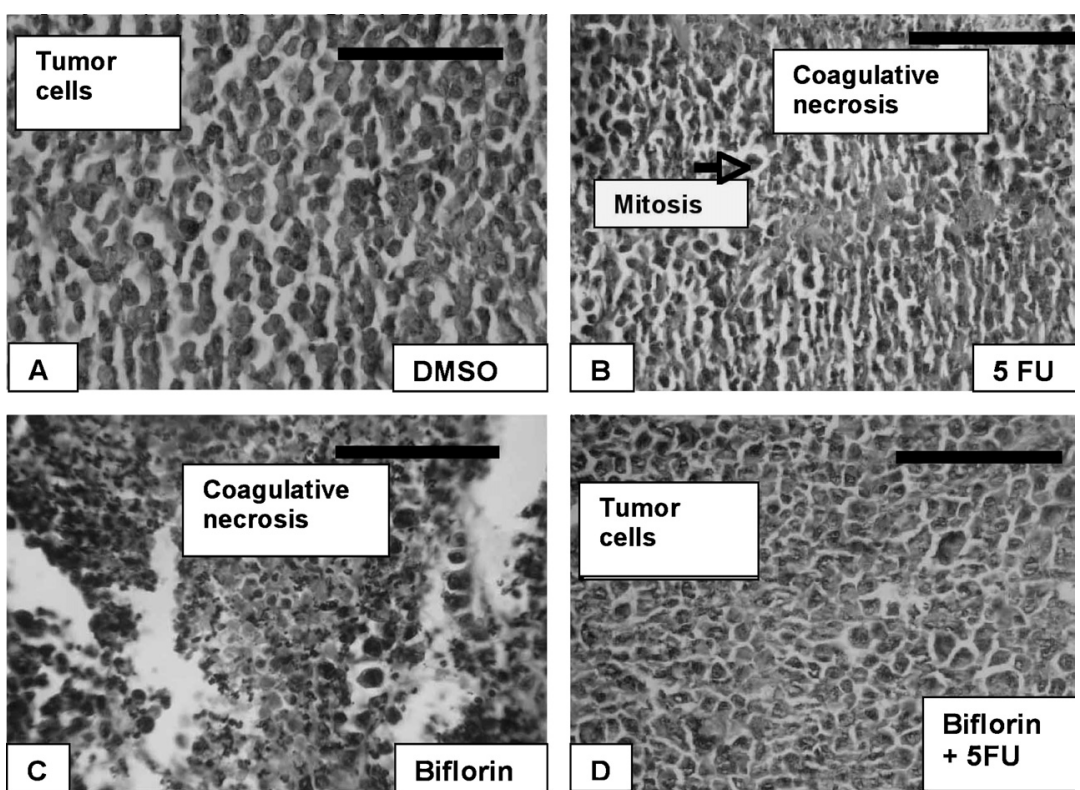

Fig. 2. Sarcoma 180 Tumors Removed on Day 8 from Animals Treated with: A) DMSO 10\%, B) 5-FU (25 mg/kg/d), C) Biflorin (50 mg/kg/d), D) Biflorin $(25 \mathrm{mg} / \mathrm{kg} / \mathrm{d})+5-\mathrm{FU}(10 \mathrm{mg} / \mathrm{kg} / \mathrm{d})$

Horizontal bars $=1 \mathrm{~mm}$.

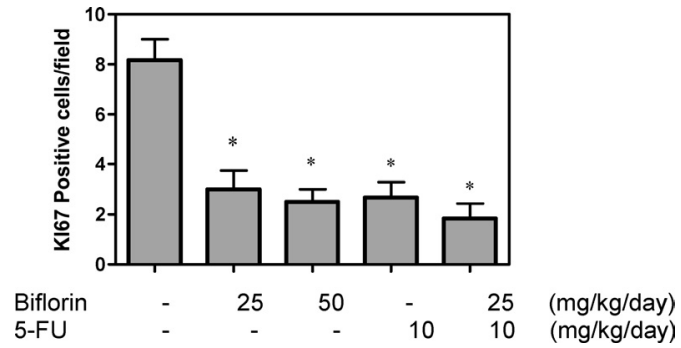

Fig. 3. Effect of Biflorin Alone and in Combination with $10 \mathrm{mg} / \mathrm{kg}$ of 5 FU on Sarcoma 180 Cell Proliferation Using Ki67 Antibody

Ki67-positive cells from $4-6$ fields/tumor slide were counted and the mean \pm S.E.M of positive cells was calculated. Saline solution was used as the negative control $10 \mathrm{mg} / \mathrm{kg} / \mathrm{d}$ of $5-\mathrm{FU}$ was used as the positive control. $* p<0.05$, ANOVA followed by Student Newman Keuls.

After treatment with biflorin $(25 \mathrm{mg} / \mathrm{kg} / \mathrm{d})$, the spleen weight of mice inoculated with sarcoma 180 was significantly increased $(p<0.05)$, while there were no differences for liver and kidney (Table 1). At the highest dose $(50 \mathrm{mg} / \mathrm{kg} / \mathrm{d})$, this augment was not observed. On the other hand, in mice inoculated with Ehrlich carcinoma, spleen weight was increased only after the treatment with biflorin at $50 \mathrm{mg} / \mathrm{kg} / \mathrm{d}(p<0.05$, Table 2$)$. In this group, it was also ob- served an increase in liver weight ( $p<0.05$, Table 2$) .5$-FU at $25 \mathrm{mg} / \mathrm{kg} / \mathrm{d}$ reduced the spleen weight of animals inoculated with both tumors $(p<0.05$, Tables 1,2$)$.

Histopathological analyses of kidneys removed from animals-treated with 5 -FU $(10,25 \mathrm{mg} / \mathrm{kg} / \mathrm{d})$, biflorin $(25$, $50 \mathrm{mg} / \mathrm{kg} / \mathrm{d}$ ) or the association of biflorin and 5-FU showed hydropic degeneration of proximal tubular epithelium but the glomeruli structure was essentially preserved.

On the other hand, histopathological analyses of the liver showed that all treated animals including control ones, that received only vehicle, showed alterations as Kupffer cells hyperplasia, intense ballooning degeneration of hepatocytes and portal tracts and centriolobular vennus congestion. Further than these alterations, animals treated with biflorin $50 \mathrm{mg} / \mathrm{kg} / \mathrm{d}, 5-\mathrm{FU}(10,25 \mathrm{mg} / \mathrm{kg} / \mathrm{d})$ or biflorin $25 \mathrm{mg} / \mathrm{kg} / \mathrm{d}+$ 5 -FU $10 \mathrm{mg} / \mathrm{kg} / \mathrm{d}$ presented also steatosis microvesicular, sinusoidal hemorrhage and focal infiltrated of chronic inflammatory cells (Fig. 4). In the spleen, biflorin-treated mice showed a discreet increase of the white pulp and nest of megakaryocytic, which suggests an immunomodulatory activity (Fig. 5).

To investigate the effect of biflorin on the induction of humoral immune response of mice immunized with OVA, the 
Table 2. Inhibition Rate of Compounded Drugs on Mice Transplanted Ehrlich Tumor

\begin{tabular}{|c|c|c|c|c|c|c|c|}
\hline Drug & $\begin{array}{c}\text { Dose } \\
(\mathrm{mg} / \mathrm{kg} / \mathrm{d})\end{array}$ & $\begin{array}{c}\text { Liver } \\
\text { (g/100 g body } \\
\text { weight) }\end{array}$ & $\begin{array}{c}\text { Spleen } \\
\text { (g/100 g body } \\
\text { weight) }\end{array}$ & $\begin{array}{c}\text { Kidney } \\
\text { (g/100 g body } \\
\text { weight) }\end{array}$ & Tumor (g) & Inhibition (\%) & $n$ \\
\hline Control & - & $5.04 \pm 0.18$ & $0.78 \pm 0.06$ & $1.14 \pm 0.03$ & $1.89 \pm 0.68$ & - & 22 \\
\hline \multirow[t]{2}{*}{ Biflorin } & 25 & $4.99 \pm 0.20$ & $0.69 \pm 0.05$ & $0.99 \pm 0.05$ & $1.99 \pm 0.38$ & 12.29 & 7 \\
\hline & 50 & $5.92 \pm 0.15^{a, c, d)}$ & $0.96 \pm 0.07^{c, d)}$ & $1.32 \pm 0.03$ & $1.24 \pm 0.33^{a)}$ & 45.39 & 9 \\
\hline \multirow{2}{*}{$5-\mathrm{FU}$} & 10 & $4.92 \pm 0.25$ & $0.65 \pm 0.07$ & $1.26 \pm 0.08$ & $1.34 \pm 0.51^{a)}$ & 41.15 & 7 \\
\hline & 25 & $4.09 \pm 0.35$ & $0.23 \pm 0.03^{a, b, c, d)}$ & $1.13 \pm 0.08$ & $0.58 \pm 0.26^{a)}$ & 74.57 & 9 \\
\hline Biflorin+5-FU & $25+10$ & $4.69 \pm 0.18$ & $0.57 \pm 0.05$ & $1.12 \pm 0.03$ & $0.47 \pm 0.19^{a, c)}$ & 79.36 & 9 \\
\hline
\end{tabular}

Data are presented as mean \pm S.E.M. from $n$ experiments. Significant differences were evaluated by ANOVA followed Student Newman Keuls. $a$ ) $p<0.05$ compared to control group. b) $p<0.05$ compared to biflorin $25 \mathrm{mg} / \mathrm{kg} / \mathrm{d}$. c) $p<0.05$ compared to biflorin $25 \mathrm{mg} / \mathrm{kg} / \mathrm{d}$ and 5 -FU $10 \mathrm{mg} / \mathrm{kg} / \mathrm{d}$ independently administered. $d$ ) $p<0.05$ compared to biflorin $25 \mathrm{mg} / \mathrm{kg} / \mathrm{d}+5-\mathrm{FU} 10 \mathrm{mg} / \mathrm{kg} / \mathrm{d}$.
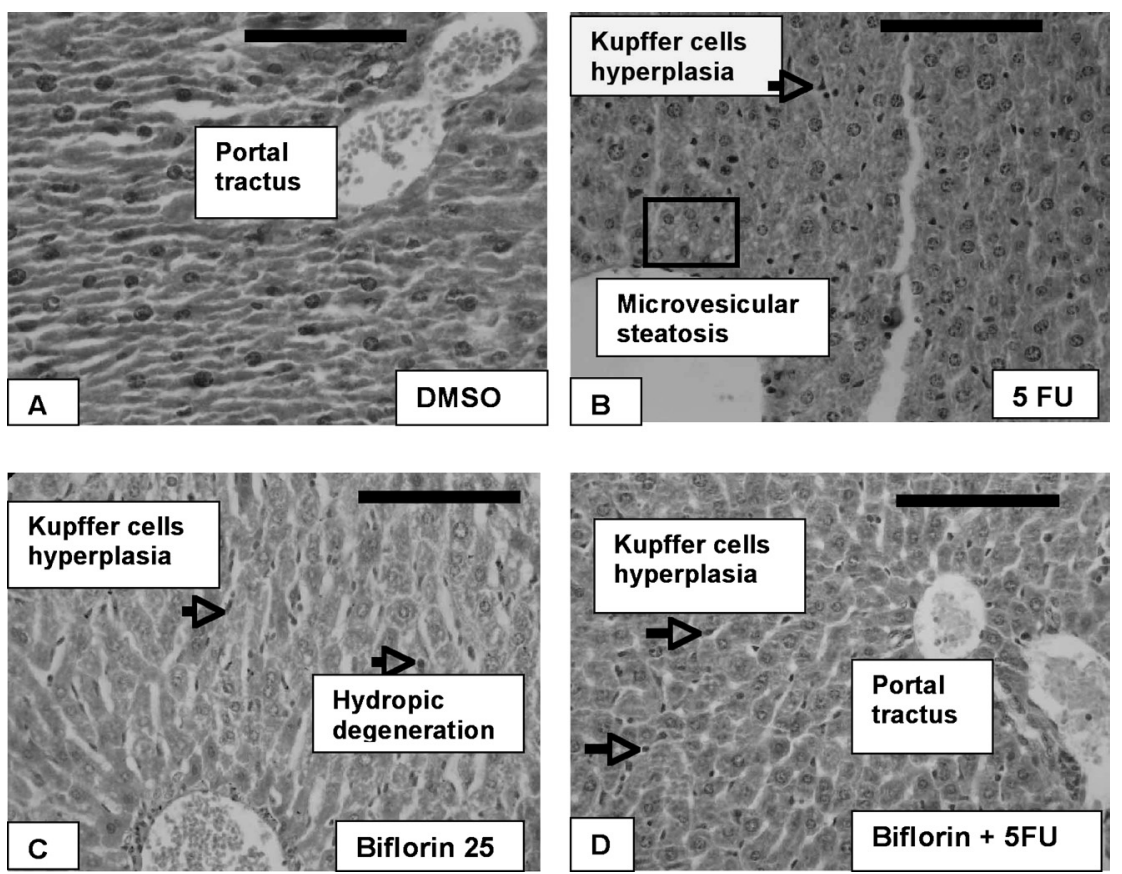

Fig. 4. Liver of the Animals Treated with: A) DMSO 10\%, B) $5-\mathrm{FU}(25 \mathrm{mg} / \mathrm{kg} / \mathrm{d}), \mathrm{C})$ Biflorin $(50 \mathrm{mg} / \mathrm{kg} / \mathrm{d}), \mathrm{D})$ Biflorin $(25 \mathrm{mg} / \mathrm{kg} / \mathrm{d})+5-\mathrm{FU}(10 \mathrm{mg} / \mathrm{kg} / \mathrm{d})$

Black arrows show Kupffer cells hyperplasia. Horizontal bars $=1 \mathrm{~mm}$.

OVA-specific antibody levels in the sera were measured prior to immunization and at 7, 14 and $21 \mathrm{~d}$ after, at the dilution of $1: 40$ by ELISA. Results are shown in Fig. 6 . The amount of OVA-specific total Ig in the sera was significantly increased by biflorin at a dose of $1.0 \mathrm{mg}(40 \mathrm{mg} / \mathrm{kg})$ compared with OVA control $(p<0.05)$.

\section{DISCUSSION}

The present work reports the antitumor activity of biflorin, an $o$-naphthoquinone isolated from C. biflora, on mice transplanted with sarcoma 180 and Erhlich carcinoma. These models are mouse-originated tumors frequently used in antitumor related research in vivo. ${ }^{15,16)}$ In fact, the naphthoquinones, mainly represented by $\beta$-lapachone, constitutes a promising group of compounds with antitumor properties. ${ }^{17-20,21)}$ Lima et al. (1972) had studied the antitumor activity of naphthoquinones, e.g. juglone, lapachol, lawsone and plumbagine, on the same experimental models as the present paper, showing that these compounds, with the exception of lapachol, were able to inhibit the sarcoma 180 tumor growth. On the other hand, all tested compounds, including lapachol, were active against Ehrlich carcinoma. $\beta$-Lapachone was active against sarcoma 180 cells in vitro and Yoshida sarcoma and Walker 256 carcinosarcoma in vivo. ${ }^{22,23)}$ Biflorin, on the other hand, presented activity against both tumors with a very similar profile.

In addition to the antitumor activity observed for biflorin alone, this compound was also able to increase the response elicited by 5 -FU in mice inoculated with both sarcoma 180 and Erlich carcinoma. This is a very interesting finding since one option to improve the efficacy of anticancer therapy is to develop optimal combination regimens of chemotherapeutic drugs, which may also reduce the side effects of the treatment.

Immunohistochemical staining of cells for proliferationassociated proteins offers information about the tumor's proliferation rate. The monoclonal antibody Ki67, described by Gerdes et al. (1983), ${ }^{24)}$ is a mouse monoclonal antibody that identifies a nuclear antigen associated with G1, S, G2 and M phases. This molecule is expressed along the entire cell cycle, except on G0 and early G1 phases. ${ }^{25)}$ Thus, results ob- 

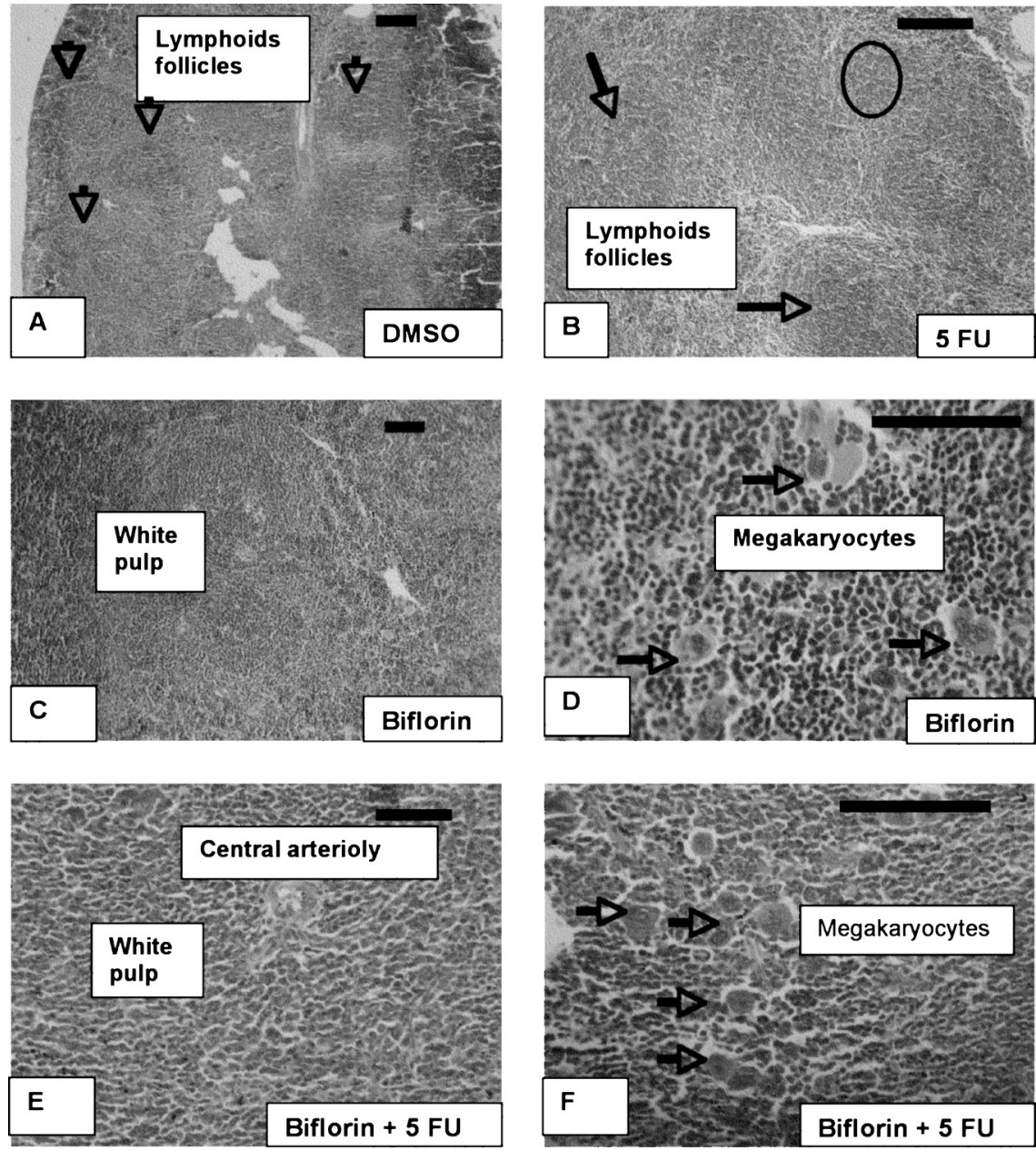

Fig. 5. Spleen of the Animals Treated with: A) DMSO 10\%, B) 5-FU (10 mg/kg/d), C, D) Biflorin $(25 \mathrm{mg} / \mathrm{kg} / \mathrm{d})$, E, F) Biflorin $(25 \mathrm{mg} / \mathrm{kg} / \mathrm{d})+5-\mathrm{FU}$ $(10 \mathrm{mg} / \mathrm{kg} / \mathrm{d})$

Horizontal bars $=1 \mathrm{~mm}$.

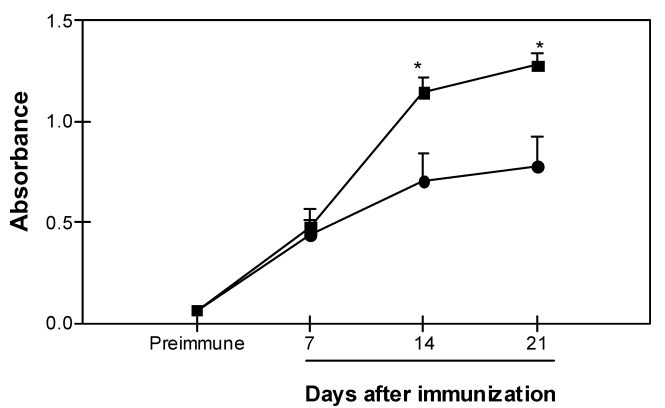

Fig. 6. Effect of Biflorin (1 mg) on OVA-Specific Total Ig Antibody

Mice were immunized subcutaneously with OVA $(50 \mu \mathrm{g}, \bullet)$ or with OVA $(50 \mu \mathrm{g})+$ biflorin $(1 \mathrm{mg}, \mathbf{\square})$. Sera were collected prior to immunization and 7, 14 and $21 \mathrm{~d}$ after immunization. Antibodies were detected by ELISA at the dilution of $1: 40$ Data are presented as mean \pm S.E.M. from 10 animals. $* p<0.05$, ANOVA followed by Student Newman Keuls.

tained with Ki67 staining in sarcoma 180 tumor reinforces that the activity of biflorin was related to a reduction in the tumor proliferation rate. In fact, it was already reported that biflorin shows a cytotoxic effect towards tumor cell lines in vitro. ${ }^{12)}$ It is worthwhile to mention that the reduction in Ki67 staining was significant even in tumors removed from animal treated with biflorin at the dose of $25 \mathrm{mg} / \mathrm{kg} / \mathrm{d}$, where the tumor weight was not significantly reduced. Ruban and Far- ber $(2002)^{26)}$ discussed the relation between tumor growth, cell proliferation and Ki67 staining, concluding that Ki67 staining analysis using tumor microsections do not necessarily represent a direct relationship with tumor size. Moreover, this marker is better related to tumor aggressiveness and malignancy. ${ }^{27)}$ Nevertheless, present data suggested that biflorin altered tumor behavior.

In a previous work, we demonstrated that in vitro antitumor properties of biflorin may differ from that described for $\beta$-lapachone and lapachol, since biflorin displayed antioxidant effects instead of prooxidant, as observed for these other naphthoquinones. ${ }^{12,20,28)}$ In fact, the mechanisms of cell death triggered by $\beta$-lapachone remains controversial. ${ }^{18)}$ Despite the induction of oxidative stress, $\beta$-lapachone inhibited the catalytic activity of topoisomerase $\mathrm{I}^{29}$ and selectively induced apoptosis in transformed cells but not in proliferating normal cells. ${ }^{19)}$

Biflorin mechanisms of tumor cell death are unknown and preliminary data suggests that this compound could trigger leukemia cell differentiation in vitro. Present data shows that biflorin significantly increased the serum antibody production in mice immunized with OVA, which indicates an immunostimulant activity for this natural naphthoquinone. Further, in mice treated with biflorin, it was observed morpho- 
logical alterations in spleen compatible also with an immunostimulant activity. ${ }^{30}$

The histopathological analyses of organs removed from treated animals suggest that biflorin possesses only a weak toxicity, since most of the observed morphological alterations in biflorin-treated animals were also seen in the control group, suggesting that these effects could be related to hepatocytes metabolism. ${ }^{31,32)}$ Nevertheless, some alterations like microvesicular steatosis accompanied by ballooning degeneration of hepatocytes were observed in biflorin and 5-FU treated animals, but these effects, according to the literature, could also be related to a weak hepatotoxicity. ${ }^{31,33,34)} \mathrm{Re}$ moval of drugs or dosage adjustment usually leads to rapid improvement. ${ }^{31)}$ The liver is an organ with great adaptive and regeneration abilities. For example, the increase in endoplasmic reticulum produced by long-term treatment with anticonvulsant drugs is commonly regarded as an adaptive phenomenon. On the other hand, regeneration of hepatic tissues occurs in many diseases, except in the most deleterious ones. Even when the hepatocellular necrosis is present, but the conjunctive tissue is preserved, the regeneration is merely complete. ${ }^{31,33)}$ Moreover, the kidney alterations observed in biflorin treated animals could also be considered discrete. ${ }^{34-36)}$

In conclusion, biflorin exhibited antitumor effects on experimental tumors without an expressive toxicity. This activity seemed to be related to its immunestimulant properties and to the reduction of tumor proliferation rate. Moreover, despite the low potency observed for the use of biflorin alone, it increased the efficacy of 5-FU. Further studies are in progress to determine its mechanism of action.

Acknowledgments The authors are grateful to the Brazilian Agencies FINEP, CNPq, BNB/FUNDECI, PRONEX, and CAPES for fellowships and financial support. Silvana França dos Santos and Luciana França provided excellent technical assistance.

\section{REFERENCES}

1) Braga R., "Plantas do Nordeste, especialmente do Ceará," 3rd ed., Mossoró, ESAM, 1976, p. 103.

2) Scofield D., http://www.cassiakeyensis.com/sofl_plants/med_ Caprariabiflora.html, 2002.

3) Serpa J., An. Fac. Med. Univ. Recife., 18, 275-288 (1958).

4) Nascimento S. C., Mello J. F., Chiappeta A. A., Rev. Inst. Antibiot. Recife., 22, 19-26 (1984).

5) Acosta S. L., Muro L. V., Sacerio A. L., Monteagudo G. L., Peña A. R., Okwel S. N., Acta Farm. Bonaerense, 22, 53-55 (2003).

6) Acosta S. L., Muro L. V., Sacerio A. L., Peña A. R., Okwei S. N., Fitoterapia, 74, 686-688 (2003).

7) Heinrich M., Rimpler H., Planta Med., 55, 626 (1989).

8) Collins D. O., Gillimore W. A., Reynolds W. R., Williams L. A. D., Reese P. B., J. Nat. Prod., 63, 1515-1518 (2000).

9) Lima G. O., D’albuquerque I. L., Rev. Inst. Antibiot. Recife., 1, 7-9 (1958).
10) Fonseca A. M., Pessoa O. D. L., Silveira E. R., Lemos T. L. G., Monte F. J. Q., Braz-Filho R., Mag. Reson. Chem., 41, 1038-1040 (2003).

11) Lima G. O., D’albuquerque I. L., Magalhães Neto B., Albuquerque M. M., Rev. Inst. Antibiot. Recife., 1, 95-98 (1958).

12) Vasconcellos M. C., Montenegro R. C., Militão G. C. G., Pessoa O. D., Fonseca A. M., Lemos T. G. L., Pessoa C., Moraes M. O., CostaLotufo L. V., Z. Naturforsch., 60c, 394-398 (2005).

13) Magalhães H. I. F., Veras M. L., Torres M. R., Alves A. P. N. N., Pessoa O. D. L., Silveira E. R., Costa-Lotufo L. V., Moraes M. O., Pessoa C., J. Pharm. Pharmacol., 58, 235-241 (2006).

14) Bezerra D. P., Castro F. O., Alves A. P. N. N., Pessoa C., Moraes M. O., Silveira E. R., Lima M. A. S., Elmiro F. J. M., Costa-Lotufo L. V., Braz. J. Med. Biol. Res., 39, 801-807 (2006).

15) Ito H., Shimura K., Itoh H., Kawade M., Anticancer Res., 17, 277284 (1987).

16) Lee Y. L., Kim H. J., Lee M. S., Kim J. M., Han J. S., Hong E. K., Kwon M. S., Lee M. J., Exp. Anim., 52, 371-375 (2003).

17) Li C. J., Li Y. Z., Pinto A. V., Pardee A. B., Curr. Cancer Drug Targets, 96, 13369-13374 (1999).

18) Li Y., Sun X., LaMont T., Pardee A. B., Li C. J., Proc. Natl. Acad. Sci. U.S.A., 100, 2674-2678 (2002).

19) Kumi-Diaka J., Saddler-Shawnette S., Aller A., Brown J., Cancer Cell Int., 4, 5 (2004).

20) Reinicke K. E., Bey E. A., Sentle M. S., Pink J. J., Ingalls S. T., Hoppel C. L., Misico R. I., Azarc G. M., Burton G., Bornamann W. G., Sutton D., Gao J., Boothman D. A., Clin. Cancer Res., 11, 30553064 (2005).

21) Lima O. G., Maciel G. M., Oliveira L. L., Lacerda A. L., Moreira L. C., Martins D. G., Rev. Inst. Antibiot. Recife., 12, 3-12 (1972).

22) Santana C. F., Lima O. G., D'Albuquerque L., Lacerda A. L., Martins D. G., Rev. Inst. Antibiot. Recife., 8, 89-94 (1968).

23) Do Campo R., Cruz F. S., Boveris A., Muniz R. P., Esquivel D. M., Biochem. Pharmacol., 28, 723-728 (1979).

24) Gerdes J., Schwab U., Lemke H., Stein H., Int. J. Cancer, 31, 13-20 (1983).

25) Gerdes J., Lemke H., Baisch H., Wacker H. H., Schwab U., Stein H., J. Immunol., 133, 1710-1715 (1984).

26) Rubin E., Farber J. L., "Patologia," 3rd ed., Guanabara-Koogan, Rio de Janeiro, Brasil, 2002, pp. 153-209.

27) Kurokawa H., Zhang M., Matsumoto S., Yamashita Y., Tanaka T., Tomoyose T., Takano H., Funaki K., Fuyuyama H., Takahashi T., Sakoda S., J. Oral Pathol. Med., 34, 602-607 (2005).

28) Bolton J. L., Trush M. A., Penning G., Dryhurst G., Monks T. J., Chem. Res. Toxicol., 13, 135-160 (2000).

29) Pardee A. B., Li Y. Z., Li C. J., Curr. Cancer Drug Targets, 2, 227242 (2002).

30) Banks W. J., "Histologia Veterinária Aplicada," 2nd ed., Editora Manole Ltda., Brasil, 1992, pp. 376-381.

31) Scheuer P. J., Lefkowitch J. H., Drugs and Toxins, "Liver Biopsy Interpretation," 6th ed., ed. by Scheuer P. J., Lefkowitch J. H., WB Saunders, London, 2000, pp. 134-150.

32) McGee J. O. D., Isaacson P. A., Wright N. A., "Oxford Textbook of Pathology: Pathology of Systems," 1st ed., Oxford University Press, New York, 1992, pp. 1330-1343.

33) Kummar V., Abbas A., Fausto N., "Robbins \& Cotran Pathology Basis of Disease," 7th ed., WB Saunders, China, 2004.

34) Torti V. R., Cobb A. J., Everitt J. I., Marshall M. W., Boorman G. A., Butterworth B. E., Toxicol. Sci., 64, 269-280.

35) Tisher C. C., Brenner B. M., "Renal Pathology: with Clinical and Functional Correlations," 2nd ed., J. B. Hippincott Company, Philadelphia, 1994, pp. 769-809.

36) Shuler C. L., Bennett W. M., “Textbook of Nephrology,” Vol. 1, 3rd ed., ed. by Massry S. G., Glassock R. J., Williams \& Wilkins, U.S.A., 1995, pp. $930-983$. 